\title{
ANALISA KESESUAIAN UNSUR PENYAJIAN PETA KELURAHAN PANYURAN BERDASARKAN PERKA BIG NO. 3 TAHUN 2016
}

\author{
Ziyadatul Rofita ${ }^{1}$, Bangun Muljo Sukojo², Udiana Wahyu Deviantari ${ }^{3}$ \\ 1,2,3 Departemen Teknik Geomatika, FTSLK-ITS, Kampus ITS Sukolilo, Surabaya, 60111, Indonesia \\ e-mail: ${ }^{2}$ bangunms@gmail.com
}

\begin{abstract}
Abstrak
Peta desa adalah peta tematik bersifat dasar yang berisi unsur dan informasi batas wilayah, infrastruktur transportasi, toponim, perairan, sarana prasarana, penutup lahan dan penggunaan lahan yang disajikan dalam beberapa bentuk peta. Keberagaman jenis peta desa yang ada di Indonesia menjadi salah satu alasan Badan Informasi Geospasial untuk membuat kebijakan standarisasi pemetaan desa yang baku sebagai acuan nasional. Pengadaan peta desa dibutuhkan untuk mempercepat proses pembangunan desa dan kawasan pedesaan dengan memanfaatkan data spasial. Hasil akhir dari penelitian ini adalah peta kelurahan yang terdiri dari peta citra, peta tutupan lahan, dan peta sarana prasarana. Penyajian peta kelurahan Panyuran disesuaikan terhadap unsur-unsur peta yang wajib ditampilkan sesuai dengan PerKa BIG No. 3 Tahun 2016. Presentase kesesuaian penyajian peta citra terhadap unsur wajib sebesar 71,43\%, unsur pilihan $0 \%$, dan unsur kondisional $91,30 \%$. Kemudian presentase kesesuaian penyajian peta tutupan lahan terhadap unsur wajib sebesar $71,43 \%$, unsur pilihan $0 \%$, dan unsur kondisional $88.89 \%$. Sedangkan presentase tingkat kesesuaian penyajian peta sarana prasarana adalah $75,00 \%$ unsur wajib, $0 \%$ unsur pilihan, dan $92,00 \%$ unsur kondisional.
\end{abstract}

Kata Kunci: Peta Desa, Pembangunan Desa, Data Spasial, Penyajian Peta

\begin{abstract}
Village map is a basic thematic map that contains elements and information on boundaries, transportation infrastructure, toponyms, waters, infrastructure, land cover and land use that are presented in several map forms. The diversity of village map types in Indonesia is one of the reasons for the Geospatial Information Agency to make a standardization policy of village mapping as a national reference. Procurement of village maps is needed to accelerate the process of village and rural development by utilizing spatial data. The final result of this study is a village map consisting of an image map, a map of land cover, and a map of infrastructure. The presentation of the Panyuran SubDistrict map is adjusted to the map elements that must be displayed in accordance with BIG Decree No. 3 of 2016. The percentage of conformity of the presentation of image maps to the mandatory elements is $71.43 \%$, $0 \%$ selected elements, and conditional elements $91.30 \%$. Then the percentage of suitability of the presentation of the map of land cover to the mandatory elements is $71.43 \%$, the optional element is $0 \%$, and the conditional element is $88.89 \%$. While the percentage of suitability of the presentation of infrastructure map is $75.00 \%$ mandatory element, $0 \%$ optional element, and $92.00 \%$ conditional element.
\end{abstract}

Keywords: Village Map, Village Development, Spatial Data, Map Presentation 


\section{PENDAHULUAN}

Menurut Undang-Undang Republik Indonesia Nomor 6 Tahun 2014 Pasal 1 Ayat 1 disebutkan bahwa desa adalah kesatuan masyarakat hukum yang memiliki batas wilayah yang berwenang untuk mengatur dan mengurus urusan pemerintahan, kepentingan masyarakat setempat berdasarkan prakarsa masyarakat, hak asal usul, dan/atau hak tradisional yang diakui dan dihormati dalam sistem pemerintahan Negara Kesatuan Republik Indonesia. Dalam usaha mewujudkan sistem pemerintahan yang baik perlu adanya pembangunan desa. Di dalam Undang-Undang Republik Indonesia Nomor 6 Tahun 2014 Pasal 78 Ayat 1 dijelaskan bahwa pelaksanaan kegiatan pembangunan desa bertujuan untuk meningkatkan kesejahteraan masyarakat desa dan kualitas hidup manusia serta penanggulangan kemiskinan melalui penyediaan pemenuhan kebutuhan dasar, pembangunan sarana dan prasarana, pengembangan potensi ekonomi lokal, serta pemanfaatan sumber daya alam dan lingkungan secara berkelanjutan.

Dalam peraturan BIG (2016) untuk melaksanakan program perencanaan pembangunan nasional setiap kementerian/ lembaga/pemerintah daerah membutuhkan peta desa. Pengadaan peta desa dibutuhkan untuk mempercepat proses pembangunan desa dan kawasan pedesaan. Menurut Abidin (2017) alasan utama dalam rangka pembuatan peta desa adalah permasalahan bentuk peta desa yang beragam sehingga diperlukan adanya program pembuatan satu peta yaitu peta desa yang memiliki standar penyajian yang paten antara peta daerah yang satu dengan daerah lainnya.

Pembuatan peta desa juga perlu memperhatikan kaidah-kaidah tentang spesifikasi penyajian peta desa yang disusun dengan maksud memberikan panduan dan acuan kepada Kementerian/Lembaga/ Pemerintah Daerah seperti yang tercantum dalam PerKa BIG No. 3 Tahun 2016.

\section{METODOLOGI PENELITIAN}

\section{Lokasi Penelitian}

Berdasarkan data dari Website Desa (2018) di Portal Kabupaten Tuban yang merupakan situs resmi Pemerintahan Kabupaten Tuban diketahui bahwa kelurahan Panyuran merupakan satusatunya kelurahan yang ada di Kecamatan Palang.

Secara astronomis kelurahan Panyuran Kelurahan Panyuran terletak pada 6 653'37,746" hingga $6^{\circ} 54^{\prime} 54,731^{\prime \prime}$ LS dan $112^{\circ} 4^{\prime} 44,522^{\prime \prime}$ hingga $112^{\circ} 5^{\prime} 40,400^{\prime \prime}$ BT. Kelurahan Panyuran memliki luas wilayah $\pm 250 \mathrm{Ha}$. Kelurahan ini terletak kurang lebih $5 \mathrm{~km}$ dari Pusat Pemerintahan Kecamatan dan $2 \mathrm{~km}$ dari Ibukota Kabupaten/Kota.

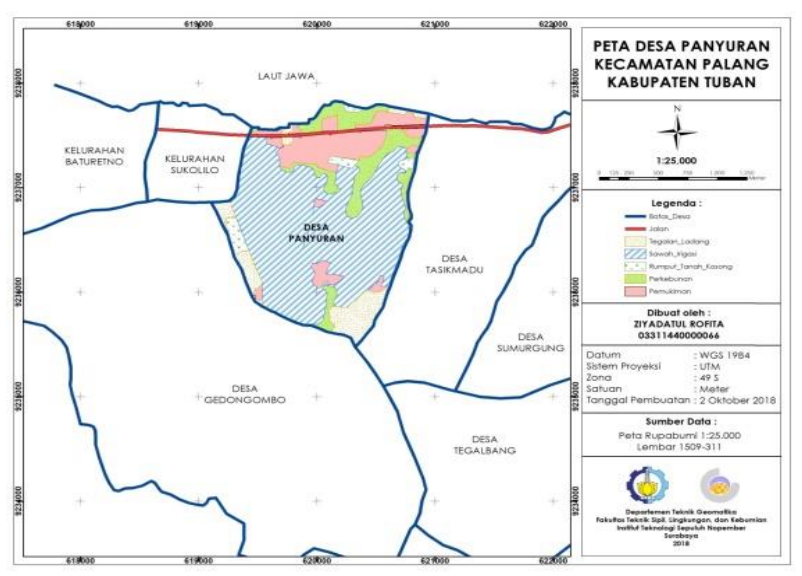

Gambar 1. Lokasi Penelitian

Batas administratif kelurahan Panyuran dibatasi oleh:

Sebelah Utara : Laut Jawa

Sebelah Timur : Kelurahan Sukolilo

Sebelah Selatan: Desa Gedongombo

Sebelah Barat : Desa Tasikmadu

\section{Data dan Peralatan}

Data yang diperlukan pada penelitian ini meliputi 2 hal yaitu :

a. Data Spasial

Data spasial berupa peta RBI Skala 1:25000 Tahun 1999, Citra Satelit Resolusi Sangat Tinggi (CSRST) Pleiades 1A Juli Tahun 2018, dan hasil pengambilan koordinat lapangan dengan GPS Handheld

b. Data Non-Spasial

1) Data primer meliputi data landmark unsurunsur rupabumi alami dan buatan, data potensi wisata, sarana dan prasarana serta data toponimi dari hasil survei lapangan

2) Data sekunder hanya meliputi data non-fisik (demografi, sosial, ekonomi dan budaya) dari pemerintah kelurahan Panyuran 
3) Dokumentasi landmark unsur-unsur rupabumi

Sedangkan peralatan yang diperlukan pada penelitian ini meliputi 2 hal yaitu:

a. Perangkat Keras (Hardware)
1) Laptop
2) GPS Handheld navigasi
3) Kamera/Handphone
4) Printer
5) Mouse
6) Flash Disk
7) Surat Tugas Survei
8) Formulir Survei

b. Perangkat Lunak (Software)

1) Microsoft Word - pembuatan laporan

2) Microsoft Excel - pendataan hasil survei toponimi

3) Microsoft Power Point - pembuatan presentasi

4) ArcGIS 10.3 untuk digitasi peta

5) $\mathrm{PCl}$ Geomatics 2015 - koreksi geometrik

\section{Tahapan Pengolahan Data}

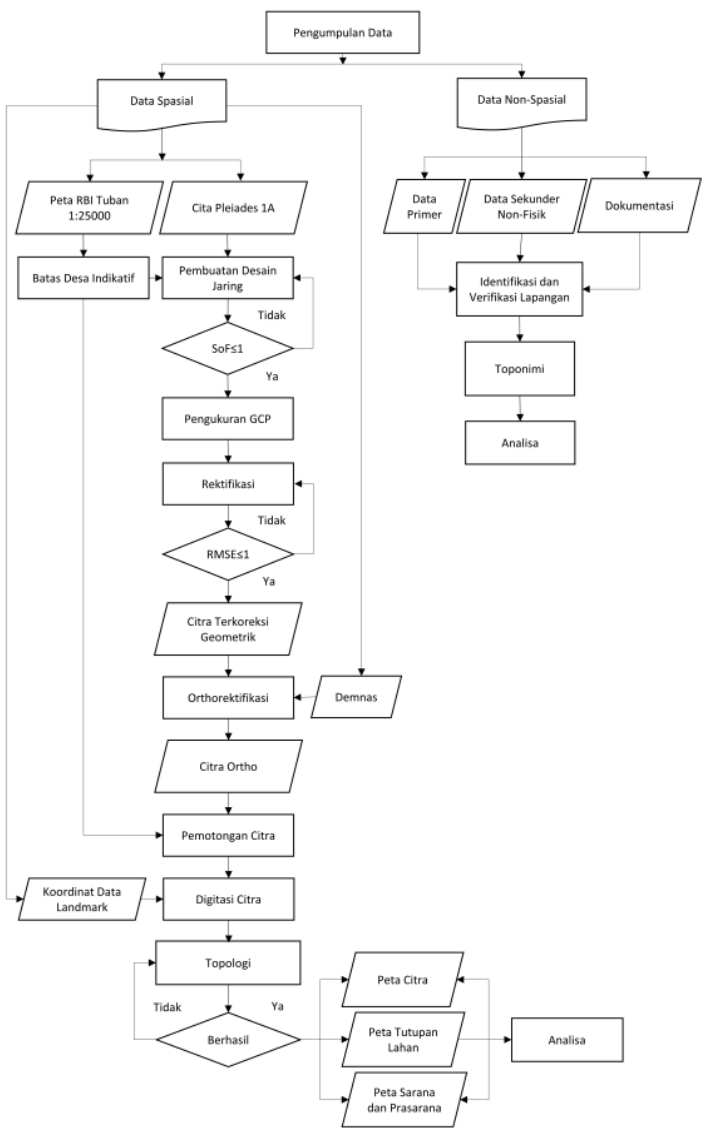

Gambar 2. Diagram Alir Pengolahan Data
Adapun pengolahan data dari penelitian ini dapat dilihat pada diagram alir Gambar 2.

\section{HASIL DAN PEMBAHASAN}

Data Citra Satelit Resolusi Sangat Tinggi (CSRT) Pleiades $1 \mathrm{~A}$ diolah untuk pembuatan peta desa skala 1:5000. Peta desa disajikan dalam 3 bentuk yaitu peta citra, peta tutupan dan penggunaan lahan, serta peta sarana dan prasarana. Untuk menilai kesesuaian unsur-unsur pada layer peta tersebut, secara kuantitatif dapat disajikan dalam nominal presentase dengan perhitungan matematika seperti yang digunakan pada penelitian Sukino (2018):

$$
\text { Kesesuaian Unsur Z (\%) = (X/Y ) x 100\% }
$$

Dimana :

Z : Unsur wajib, pilihan, atau kondisional

$X$ : Jumlah unsur yang ada dari peta yang dibuat

$\mathrm{Y}$ : Jumlah unsur dari PerKa BIG

Berikut adalah hasil dari penyajian peta kelurahan Panyuran:

\section{Peta Citra}

Pada Gambar 3 dapat dilihat hasil layout dari peta citra kelurahan Panyuran yang merupakan wilayah pesisir karena berbatasan langsung dengan Pantai Utara/Laut Jawa. Kenampakan citra kelurahan Panyuran sangat cerah dan tidak berawan karena proses perekaman data citra diambil pada bulan Juli dimana Indonesia pada saat itu merupakan musim kemarau.

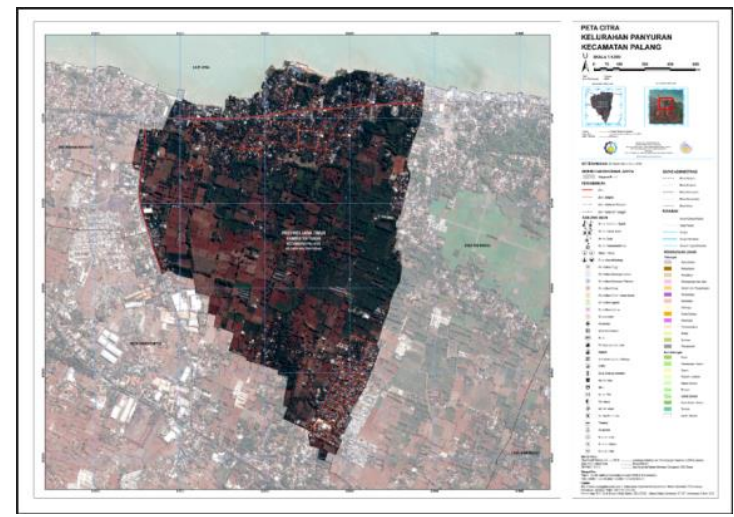

Gambar 3. Peta Citra Kelurahan Panyuran

Analisa kesesuaian layer peta citra kelurahan Panyuran terhadap PerKa BIG Nomor 3 Tahun 2016 ditampilkan pada tabel berikut. 
Tabel 1. Hasil Analisa Unsur Wajib yang Dimasukkan di dalam Layer Peta Citra Kelurahan Panyuran

\begin{tabular}{|c|c|c|c|}
\hline No & Unsur & $\begin{array}{c}\text { Menurut } \\
\text { PerKa } \\
\text { BIG }\end{array}$ & $\begin{array}{c}\text { Menurut } \\
\text { Hasil } \\
\text { Peta }\end{array}$ \\
\hline \multirow[t]{6}{*}{$\underline{1}$} & \multicolumn{3}{|c|}{ Toponimi } \\
\hline & $\begin{array}{l}\text { a. Nama daerah } \\
\text { propinsi }\end{array}$ & $\mathrm{V}$ & $\sqrt{ }$ \\
\hline & $\begin{array}{l}\text { b. Nama daerah } \\
\text { kabupaten/kota }\end{array}$ & $\sqrt{ }$ & $\sqrt{ }$ \\
\hline & c. Nama kecamatan & $\sqrt{ }$ & $\sqrt{ }$ \\
\hline & d. Nama desa & v & $\sqrt{ }$ \\
\hline & $\begin{array}{l}\text { e. Nama fasilitas } \\
\text { umum dan sosial }\end{array}$ & $\mathrm{V}$ & $x$ \\
\hline \multirow[t]{2}{*}{2} & \multicolumn{3}{|c|}{ Batas Wilayah Administrasi } \\
\hline & $\begin{array}{l}\text { a. Batas } \\
\text { desa/kelurahan }\end{array}$ & $\mathrm{V}$ & $\sqrt{ }$ \\
\hline \multirow[t]{2}{*}{$\underline{3}$} & \multicolumn{3}{|c|}{ Perairan } \\
\hline & a. Sungai & $\mathrm{V}$ & $\mathrm{X}$ \\
\hline
\end{tabular}

Berdasarkan Tabel 1, kesesuaian unsur wajib yang ada pada peta citra kelurahan Panyuran sebesar $71,43 \%$ artinya peta tersebut hanya memenuhi 5 dari 7 unsur wajib penyajian peta citra. Dua unsur yang tidak terpenuhi pada penyajian peta citra kelurahan Panyuran adalah penamaan fasilitas umum dan sosial serta tidak adanya gambaran sungai.

Tabel 2. Hasil Analisa Unsur Pilihan yang Dimasukkan di dalam Layer Peta Citra Kelurahan Panyuran

\begin{tabular}{|c|c|c|c|}
\hline No & Unsur & $\begin{array}{l}\text { Menurut } \\
\text { PerKa } \\
\text { BIG }\end{array}$ & $\begin{array}{c}\text { Menurut } \\
\text { Hasil } \\
\text { Peta }\end{array}$ \\
\hline 1 & \multicolumn{3}{|c|}{ Batas Wilayah Administrasi } \\
\hline & $\begin{array}{l}\text { a. Batas dusun/dukuh } \\
\text { atau padanan } \\
\text { sebutan pembagian } \\
\text { wilayah desa }\end{array}$ & $\mathrm{v}$ & $x$ \\
\hline & $\begin{array}{l}\text { b. Batas RW/padanan } \\
\text { sebutan pembagian } \\
\text { wilayah desa }\end{array}$ & $\sqrt{ }$ & $x$ \\
\hline & $\begin{array}{l}\text { c. Batas RT atau } \\
\text { padanan sebutan } \\
\text { pembagian wilayah }\end{array}$ & $\sqrt{ }$ & $x$ \\
\hline & $\begin{array}{l}\text { d. Batas } \mathrm{RW} / \text { padanan } \\
\text { sebutan pembagian } \\
\text { wilayah desa }\end{array}$ & v & $x$ \\
\hline & $\begin{array}{l}\text { e. Batas RT atau } \\
\text { padanan sebutan }\end{array}$ & v & $x$ \\
\hline
\end{tabular}

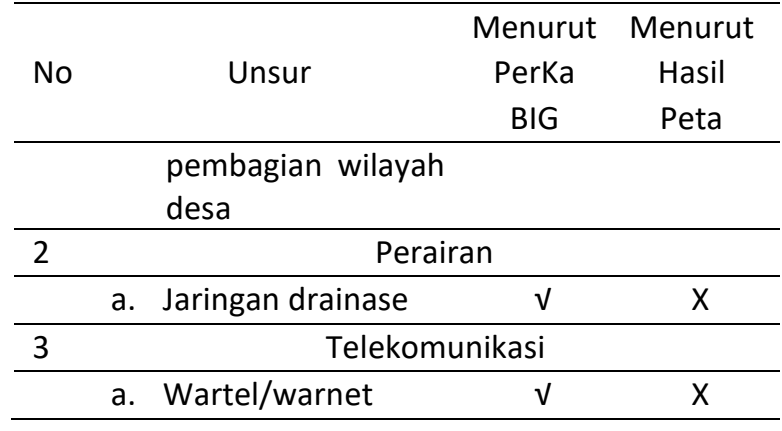

Berdasarkan Tabel 2. kesesuaian unsur pilihan yang ada pada peta citra kelurahan Panyuran sebesar 00,00\%. Sesuai dengan hasil survei di lapangan, kelurahan Panyuran tidak memiliki batas RW maupun RT. Batas terkecil yang ada hanya batas desa/kelurahan. Selain itu, di kelurahan Panyuran juga tidak terdapat jaringan drainase ataupun wartel. Sehingga dapat diartikan bahwa tidak ada unsur-unsur pilihan yang terpenuhi pada penyajian peta citra kelurahan Panyuran.

Tabel 3. Hasil Analisa Unsur Kondisional yang Dimasukkan di dalam Layer Peta Citra Kelurahan Panyuran

\begin{tabular}{|c|c|c|c|}
\hline No & Unsur & $\begin{array}{l}\text { Menurut } \\
\text { PerKa BIG }\end{array}$ & $\begin{array}{l}\text { Menurut } \\
\text { Hasil Peta }\end{array}$ \\
\hline 1 & \multicolumn{3}{|c|}{ Toponimi } \\
\hline & \multirow{2}{*}{$\begin{array}{l}\text { a. Nama perairan } \\
\text { b. Nama jalan }\end{array}$} & $\mathrm{V}$ & $\mathrm{V}$ \\
\hline & & $\mathrm{v}$ & $\mathrm{v}$ \\
\hline \multirow[t]{3}{*}{2} & \multicolumn{3}{|c|}{ Batas Wilayah Administrasi } \\
\hline & $\begin{array}{l}\text { a. Batas kabupaten/ } \\
\text { kota }\end{array}$ & $\mathrm{v}$ & $\mathrm{V}$ \\
\hline & b. Batas kecamatan & $\mathrm{V}$ & $\mathrm{V}$ \\
\hline \multirow[t]{5}{*}{3} & \multicolumn{3}{|c|}{ Jaringan/Infrastruktur Transportasi } \\
\hline & a. Jalan kolektor & V & $\mathrm{V}$ \\
\hline & b. Jalan lokal & $v$ & $\mathrm{~V}$ \\
\hline & c. Jalan pematang & $\mathrm{V}$ & $x$ \\
\hline & d. Jembatan & $\mathrm{v}$ & $x$ \\
\hline 4 & \multicolumn{3}{|c|}{ Perairan } \\
\hline & a. Garis pantai & $\mathrm{V}$ & $\mathrm{V}$ \\
\hline 5 & \multicolumn{3}{|c|}{ Sarana dan Prasarana } \\
\hline
\end{tabular}




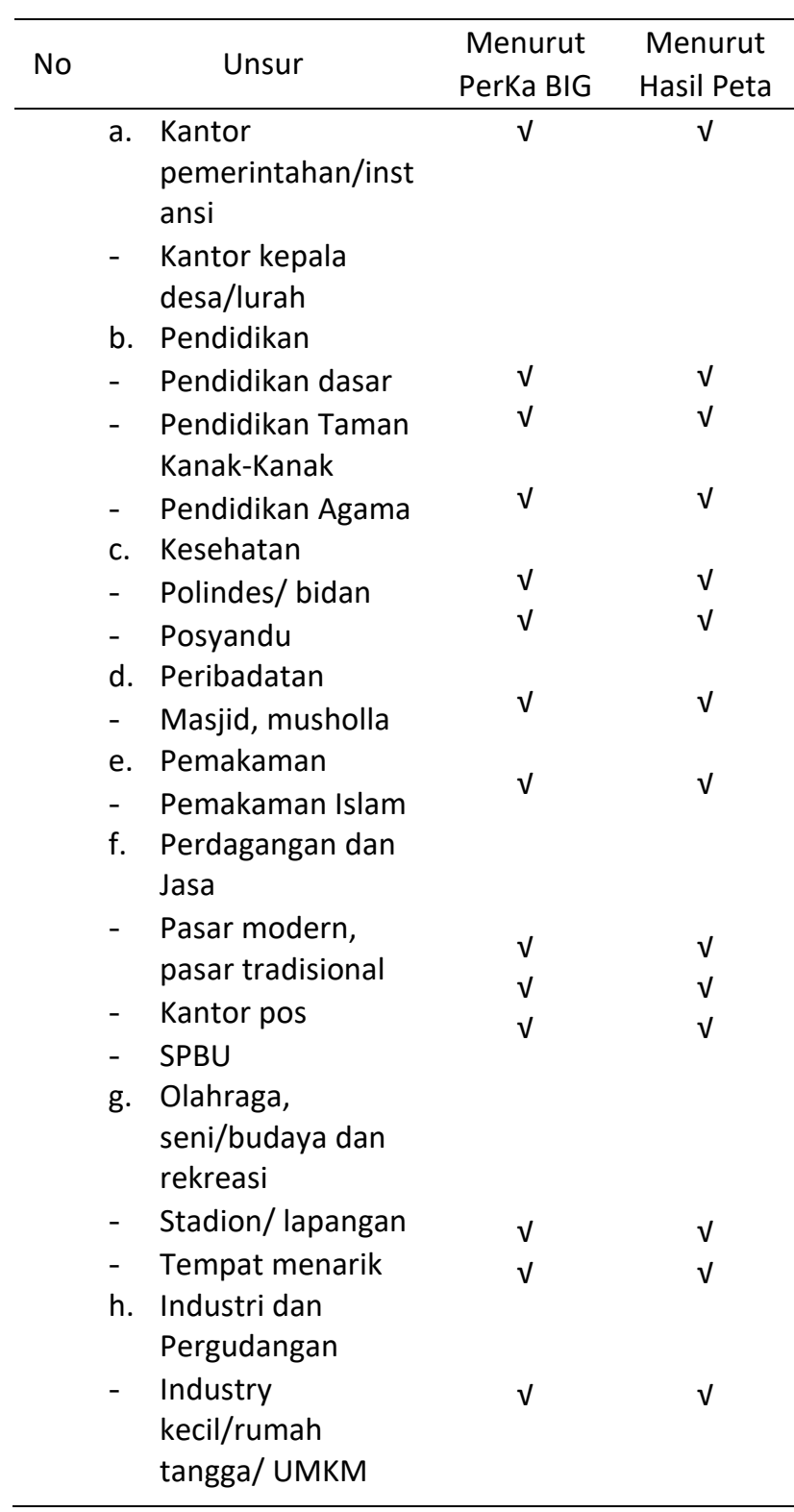

Berdasarkan Tabel 3. kesesuaian unsur kondisional yang ada pada peta citra kelurahan Panyuran sebesar 91,30\%. Dimana 23 dari 25 layer kondisional telah memenuhi syarat penyajian peta citra. Sedangkan dua layer kondisional yang tidak digambarkan pada peta citra berasal dari unsur jaringan/infrastruktur transportasi yaitu jalan pematang dan jembatan.

\section{Peta Tutupan Lahan}

Hasil digitasi peta tutupan lahan di kelurahan Panyuran dapat dilihat pada Gambar 4. Pada gambar tersebut dapat dianalisa bahwa sebagian besar wilayah kelurahan Panyuran didominasi oleh warna kuning, abu-abu muda, dan hijau muda. Ketiga warna itu dapat diidentifikasi melalui legenda yang tertera pada sisi kanan peta yaitu lahan tegalan/ladang untuk warna kuning, pemukiman warga untuk warna abu-abu, dan perkebunan untuk warna hijau muda.

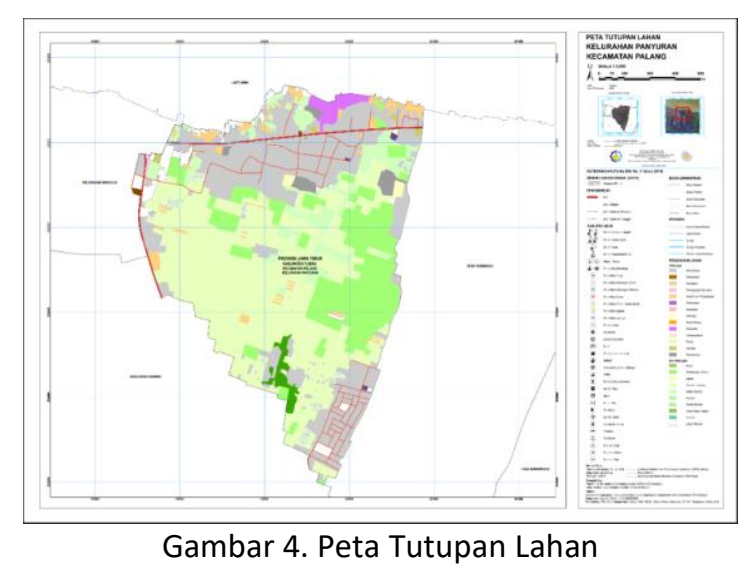

Analisa kesesuaian layer peta tutupan lahan kelurahan Panyuran terhadap PerKa BIG Nomor 3 Tahun 2016 ditampilkan pada table berikut.

Tabel 4. Hasil Analisa Unsur Wajib yang Dimasukkan di dalam Layer Peta Tutupan Lahan Kelurahan Panyuran

\begin{tabular}{|c|c|c|c|}
\hline No & Unsur & $\begin{array}{c}\text { Menurut } \\
\text { PerKa } \\
\text { BIG }\end{array}$ & $\begin{array}{c}\text { Menurut } \\
\text { Hasil } \\
\text { Peta }\end{array}$ \\
\hline \multirow[t]{6}{*}{1} & \multicolumn{3}{|c|}{ Toponimi } \\
\hline & $\begin{array}{l}\text { a. Nama daerah } \\
\text { propinsi }\end{array}$ & $\mathrm{V}$ & $\sqrt{ }$ \\
\hline & $\begin{array}{l}\text { b. Nama daerah } \\
\text { kabupaten/kota }\end{array}$ & 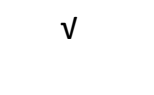 & $v$ \\
\hline & c. Nama kecamatan & $\sqrt{ }$ & $\sqrt{ }$ \\
\hline & d. Nama desa & v & v \\
\hline & $\begin{array}{l}\text { e. Nama fasilitas } \\
\text { umum dan sosial }\end{array}$ & 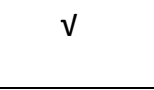 & $x$ \\
\hline \multirow[t]{2}{*}{2} & \multicolumn{3}{|c|}{ Batas Wilayah Administrasi } \\
\hline & $\begin{array}{ll}\text { a. } & \text { Batas } \\
& \text { desa/kelurahan }\end{array}$ & $\mathrm{v}$ & $\sqrt{ }$ \\
\hline \multirow[t]{2}{*}{3} & Pe & & \\
\hline & a. Sungai & $\mathrm{V}$ & $\mathrm{X}$ \\
\hline
\end{tabular}

Berdasarkan Tabel 4, kesesuaian unsur wajib yang ada pada peta tutupan lahan kelurahan Panyuran sebesar $71,43 \%$ artinya peta tersebut hanya memenuhi 5 dari 7 unsur wajib penyajian peta tutupan lahan. Dua unsur yang tidak terpenuhi pada penyajian peta tutupan lahan kelurahan Panyuran adalah penamaan fasilitas umum dan sosial serta tidak adanya gambaran sungai. 
Tabel 5. Hasil Analisa Unsur Pilihan yang Dimasukkan di dalam Layer Peta Tutupan Lahan Kelurahan Panyuran

\begin{tabular}{|c|c|c|c|}
\hline No & Unsur & $\begin{array}{c}\text { Menurut } \\
\text { PerKa BIG }\end{array}$ & $\begin{array}{c}\text { Menurut } \\
\text { Hasil } \\
\text { Peta }\end{array}$ \\
\hline \multirow[t]{6}{*}{1} & \multicolumn{3}{|c|}{ Batas Wilayah Administrasi } \\
\hline & $\begin{array}{l}\text { a. Batas dusun/dukuh } \\
\text { atau padanan } \\
\text { sebutan pembagian } \\
\text { wilayah desa }\end{array}$ & $\mathrm{V}$ & $\mathrm{X}$ \\
\hline & $\begin{array}{l}\text { b. Batas RW/padanan } \\
\text { sebutan } \\
\text { pembagian wilayah } \\
\text { desa }\end{array}$ & $\sqrt{ }$ & $x$ \\
\hline & $\begin{array}{l}\text { Batas RT atau } \\
\text { padanan sebutan } \\
\text { pembagian wilayah }\end{array}$ & $\sqrt{ }$ & $x$ \\
\hline & $\begin{array}{l}\text { d. Batas RW/padanan } \\
\text { sebutan } \\
\text { pembagian wilayah } \\
\text { desa }\end{array}$ & $\sqrt{ }$ & $x$ \\
\hline & $\begin{array}{l}\text { e. Batas RT atau } \\
\text { padanan sebutan } \\
\text { pembagian wilayah } \\
\text { desa }\end{array}$ & $\sqrt{ }$ & $x$ \\
\hline 2 & \multicolumn{3}{|c|}{ Perairan } \\
\hline & a. Jaringan drainase & $\mathrm{V}$ & $X$ \\
\hline
\end{tabular}

Berdasarkan Tabel 5, kesesuaian unsur pilihan yang ada pada peta tutupan lahan kelurahan Panyuran sebesar 00,00\%. Sesuai dengan hasil survei di lapangan, kelurahan Panyuran tidak memiliki batas RW maupun RT. Batas terkecil yang ada hanya batas desa/kelurahan. Selain itu, di kelurahan Panyuran juga tidak terdapat jaringan drainase. Sehingga dapat diartikan bahwa tidak ada unsur-unsur pilihan yang terpenuhi pada penyajian peta tutupan lahan kelurahan Panyuran.

Tabel 6. Hasil Analisa Unsur Kondisional yang Dimasukkan di dalam Layer Peta Peta Tutupan Lahan Kelurahan Panyuran

\begin{tabular}{lccc}
\hline No & Unsur & $\begin{array}{r}\text { Menurut } \\
\text { PerKa BIG }\end{array}$ & $\begin{array}{c}\text { Menurut } \\
\text { Hasil Peta }\end{array}$ \\
\hline 1 & \multicolumn{4}{c}{ Toponimi } \\
\hline & a. Nama perairan & $\mathrm{V}$ & $\mathrm{V}$ \\
& b. Nama jalan & $\mathrm{V}$ & $\mathrm{V}$ \\
\hline 2 & \multicolumn{4}{c}{ Batas Wilayah Administrasi } \\
\hline \multicolumn{4}{c}{}
\end{tabular}

\begin{tabular}{llcc}
\hline No & \multicolumn{1}{c}{ Unsur } & $\begin{array}{c}\text { Menurut } \\
\text { PerKa BIG }\end{array}$ & $\begin{array}{c}\text { Menurut } \\
\text { Hasil Peta }\end{array}$ \\
\hline & $\begin{array}{l}\text { a. Batas kabupaten/ } \\
\text { kota }\end{array}$ & $\mathrm{V}$ & $\mathrm{V}$ \\
& b. Batas kecamatan & $\mathrm{V}$ & $\mathrm{V}$ \\
\hline 3 & \multicolumn{2}{c}{ Jaringan/Infrastruktur Transportasi } \\
\hline \multirow{3}{*}{ a. Jalan kolektor } & $\mathrm{V}$ & $\mathrm{V}$ \\
& b. Jalan lokal & $\mathrm{V}$ & $\mathrm{V}$ \\
& c. Jalan pematang & $\mathrm{V}$ & $\mathrm{X}$ \\
& d. Jembatan & $\mathrm{V}$ & $\mathrm{X}$ \\
\hline 4 & & Perairan & \\
\hline & a. Garis pantai & $\mathrm{V}$ & $\mathrm{V}$ \\
\hline
\end{tabular}

5 Penutup dan Penggunaan Lahan Terbangun dan Tidak Terbangun

$\begin{array}{lll}\text { a. Bangunan gedung } & \mathrm{V} & \mathrm{V} \\ \text { b. Tempat tinggal } & \mathrm{V} & \mathrm{V} \\ \text { c. Perkantoran } & \mathrm{V} & \mathrm{V} \\ \text { d. Pendidikan } & \mathrm{V} & \mathrm{V} \\ \text { e. Perdagangan dan } & \mathrm{V} & \mathrm{V} \\ \quad \text { jasa } & & \\ \text { f. Industry dan } & \mathrm{V} & \mathrm{V} \\ \quad \text { pergudangan } & & \\ \text { g. Peribadatan } & \mathrm{V} & \mathrm{V} \\ \text { h. Kesehatan } & \mathrm{V} & \mathrm{V} \\ \text { i. Olahraga } & \mathrm{V} & \mathrm{V} \\ \text { j. Tempat } & \mathrm{V} & \mathrm{V}\end{array}$
menarik/pariwisat

a

k. Pemakaman

I. Hutan

m. Perkebunan

n. Tegalan/ladang

o. Kebun campur

p. Rumput

q. Semak belukar

r. Lahan terbuka (tanah kosong)

Berdasarkan Tabel 6. kesesuaian unsur kondisional yang ada pada peta tutupan lahan kelurahan Panyuran sebesar $88,89 \%$. Jumlah unsurunsur kondisional sangat mendominasi proses penyajian peta. Pada peta ini layer kondisional yang berhasil digambarkan pada peta sebanyak 24 dari total 27 layer. Selain jalan pematang dan jembatan seperti pada penyajian peta citra, terdapat satu layer tambahan yang tidak ada yaitu semak belukar.

\section{Peta Sarana dan Prasarana}

Peta Sarana dan Prasarana dapat dilihat pada Gambar 5 berikut. 


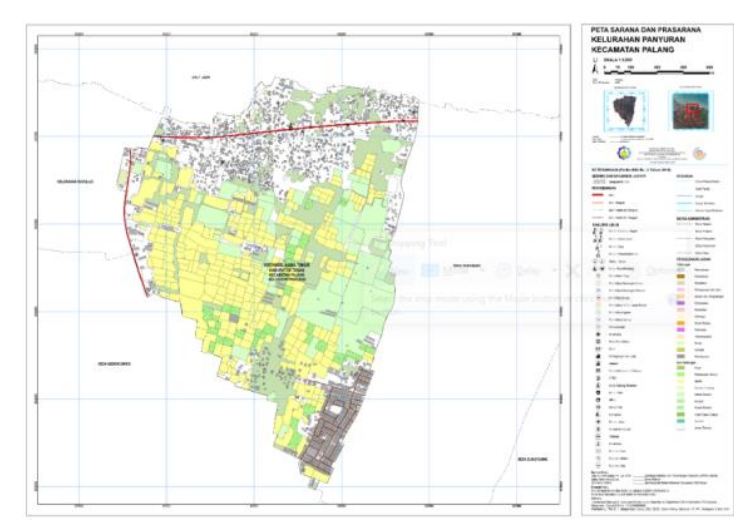

Gambar 5. Peta Sarana dan Prasarana

Peta Sarana dan Prasarana pada Gambar 5. memiliki 9 komponen fasilitas umum yang ditampilkan yaitu pendidikan dasar, pendidikan taman kanak-kanak, pendidikan agama, masjid, kantor lurah, kesehatan, stadion/bangunan olahraga, perdagangan dan jasa, SPBU, kantor pos, makam islam, dan pariwisata.

Analisa kesesuaian layer peta sarana dan prasarana kelurahan Panyuran terhadap PerKa BIG Nomor 3 Tahun 2016 ditampilkan pada table berikut.

Tabel 7. Hasil Analisa Unsur Wajib yang Dimasukkan di dalam Layer Peta Sarana dan Prasarana Kelurahan Panyuran

\begin{tabular}{|c|c|c|c|}
\hline No & Unsur & $\begin{array}{l}\text { Menurut } \\
\text { PerKa BIG }\end{array}$ & $\begin{array}{l}\text { Menurut } \\
\text { Hasil Peta }\end{array}$ \\
\hline \multirow[t]{6}{*}{1} & \multicolumn{3}{|c|}{ Toponimi } \\
\hline & $\begin{array}{l}\text { a. Nama daerah } \\
\text { propinsi }\end{array}$ & $\mathrm{V}$ & $\sqrt{ }$ \\
\hline & $\begin{array}{l}\text { b. Nama daerah } \\
\text { kabupaten/ } \\
\text { kota }\end{array}$ & $\sqrt{ }$ & $\checkmark$ \\
\hline & $\begin{array}{l}\text { c. Nama } \\
\text { kecamatan }\end{array}$ & $v$ & $v$ \\
\hline & d. Nama desa & $\sqrt{ }$ & $\sqrt{ }$ \\
\hline & $\begin{array}{l}\text { e. Nama fasilitas } \\
\text { umum dan } \\
\text { sosial }\end{array}$ & $v$ & $x$ \\
\hline \multirow[t]{2}{*}{2} & \multicolumn{3}{|c|}{ Batas Wilayah Administrasi } \\
\hline & $\begin{array}{l}\text { a. Batas desa/ } \\
\text { kelurahan }\end{array}$ & $\mathrm{V}$ & $\mathrm{V}$ \\
\hline \multirow[t]{2}{*}{3} & \multicolumn{3}{|c|}{ Perairan } \\
\hline & a. Sungai & $\mathrm{V}$ & $\mathrm{X}$ \\
\hline \multirow[t]{2}{*}{4} & \multicolumn{3}{|c|}{ Sarana dan Prasarana } \\
\hline & $\begin{array}{l}\text { a. Bangunan } \\
\text { - Bangunan } \\
\text { tempat tinggal }\end{array}$ & 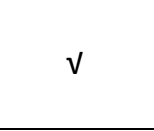 & $v$ \\
\hline
\end{tabular}

Berbeda dengan peta citra dan peta tutupan lahan. Unsur wajib penyajian peta sarana dan prasarana memiliki satu layer tambahan yaitu bangunan tempat tinggal. Berdasarkan Tabel 7, kesesuaian unsur wajib yang ada pada peta sarana dan prasarana kelurahan Panyuran sebesar $75,00 \%$ dimana 6 dari 8 unsur wajib telah memenuhi syarat penyajian peta sarana dan prasarana. Dua unsur yang tidak digambarkan pada penyajian peta tersebut adalah penamaan fasilitas umum dan sosial serta sungai karena, berdasarkan survei di lapangan daerah ini tidak dilewati sungai.

Tabel 8. Hasil Analisa Unsur Pilihan yang Dimasukkan di dalam Layer Peta Sarana dan Prasarana Kelurahan Panyuran

\begin{tabular}{|c|c|c|c|}
\hline No & Unsur & $\begin{array}{c}\text { Menurut } \\
\text { PerKa BIG }\end{array}$ & $\begin{array}{l}\text { Menurut } \\
\text { Hasil Peta }\end{array}$ \\
\hline
\end{tabular}

\begin{tabular}{|c|c|c|c|}
\hline 1 & \multicolumn{3}{|c|}{ Batas Wilayah Administrasi } \\
\hline & $\begin{array}{l}\text { a. Batas dusun/dukuh } \\
\text { atau padanan } \\
\text { sebutan pembagian } \\
\text { wilayah desa }\end{array}$ & $\sqrt{ }$ & $X$ \\
\hline & $\begin{array}{l}\text { b. Batas RW atau } \\
\text { padanan sebutan } \\
\text { pembagian wilayah } \\
\text { desa }\end{array}$ & $\sqrt{ }$ & $x$ \\
\hline & $\begin{array}{l}\text { c. Batas RT atau } \\
\text { padanan sebutan } \\
\text { pembagian wilayah } \\
\text { desa }\end{array}$ & $\sqrt{ }$ & $x$ \\
\hline 2 & \multicolumn{3}{|c|}{ Perairan } \\
\hline & a. Jaringan drainase & $\sqrt{ }$ & $\mathrm{X}$ \\
\hline 3 & \multicolumn{3}{|c|}{ Telekomunikasi } \\
\hline & a. Wartel/ warnet & $\sqrt{ }$ & $X$ \\
\hline
\end{tabular}

Berdasarkan Tabel 8, kesesuaian unsur pilihan yang ada pada peta sarana dan prasarana kelurahan Panyuran sebesar 00,00\%. Sama dengan penyajian peta citra dan peta tutupan lahan bahwa sesuai dengan hasil survei di lapangan, kelurahan Panyuran tidak memiliki batas RW maupun RT. Batas terkecil yang ada hanya batas desa/kelurahan. Selain itu, di kelurahan Panyuran juga tidak terdapat jaringan drainase. Sehingga dapat diartikan bahwa tidak ada unsur-unsur pilihan yang terpenuhi pada penyajian peta sarana dan prasarana kelurahan Panyuran. 
Tabel 9. Hasil Analisa Unsur Kondisional yang Dimasukkan di dalam Layer Peta Sarana dan Prasarana Kelurahan Panyuran

\begin{tabular}{|c|c|c|c|}
\hline No & Unsur & $\begin{array}{l}\text { Menurut } \\
\text { PerKa BIG }\end{array}$ & $\begin{array}{l}\text { Menurut } \\
\text { Hasil Peta }\end{array}$ \\
\hline 1 & \multicolumn{3}{|c|}{ Toponimi } \\
\hline & \multirow{2}{*}{$\begin{array}{l}\text { a. Nama perairan } \\
\text { b. Nama jalan }\end{array}$} & $\sqrt{ }$ & $\mathrm{V}$ \\
\hline & & $\mathrm{V}$ & $\checkmark$ \\
\hline \multirow[t]{3}{*}{2} & \multicolumn{3}{|c|}{ Batas Wilayah Administrasi } \\
\hline & \multirow{2}{*}{$\begin{array}{l}\text { a. Batas kabupaten/kota } \\
\text { b. Batas kecamatan }\end{array}$} & $\mathrm{V}$ & $\sqrt{ }$ \\
\hline & & $\mathrm{V}$ & $\checkmark$ \\
\hline \multirow[t]{5}{*}{3} & \multicolumn{3}{|c|}{ Jaringan/Infrastruktur Transportasi } \\
\hline & a. Jalan kolektor & $\mathrm{V}$ & $\sqrt{ }$ \\
\hline & b. Jalan lokal & V & 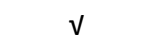 \\
\hline & c. Jalan pematang & v & $\mathrm{x}$ \\
\hline & d. Jembatan & $\checkmark$ & $x$ \\
\hline 4 & \multicolumn{3}{|c|}{ Perairan } \\
\hline & a. Garis pantai & $\mathrm{V}$ & $\mathrm{V}$ \\
\hline \multirow[t]{21}{*}{5} & \multicolumn{3}{|c|}{ Sarana dan Prasarana } \\
\hline & $\begin{array}{l}\text { a. Kantor pemerintahan/ } \\
\text { instansi }\end{array}$ & & \\
\hline & $\begin{array}{ll}\text { - Kantor } & \text { kepala } \\
\text { desa/lurah } & \end{array}$ & $\checkmark$ & $\checkmark$ \\
\hline & $\begin{array}{l}\text { b. Pendidikan } \\
\text { - Pendidikan dasar }\end{array}$ & & \\
\hline & & $v$ & $v$ \\
\hline & $\begin{array}{ll}\text { - Pendidikan } & \text { Taman } \\
\text { Kanak-Kanak } & \end{array}$ & 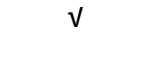 & 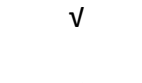 \\
\hline & - Pendidikan Agama & $\sqrt{ }$ & 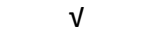 \\
\hline & c. Kesehatan & & \\
\hline & - Polindes/bidan & V & V \\
\hline & - Posyandu & v & V \\
\hline & $\begin{array}{l}\text { d. Peribadatan } \\
\text { - Masjid, musholla }\end{array}$ & $v$ & $v$ \\
\hline & $\begin{array}{l}\text { e. Pemakaman } \\
\text { - Pemakaman Islam } \\
\text { f. Perdagangan dan Jasa }\end{array}$ & $\checkmark$ & $v$ \\
\hline & $\begin{array}{l}\text { - Pasar modern, pasar } \\
\text { tradisional }\end{array}$ & 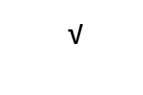 & $v$ \\
\hline & - Kantor pos & $\checkmark$ & v \\
\hline & - SPBU & 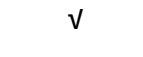 & $v$ \\
\hline & $\begin{array}{l}\text { g. Olahraga, seni/budaya } \\
\text { dan rekreasi }\end{array}$ & & \\
\hline & - Stadion/lapangan & $v$ & $v$ \\
\hline & $\begin{array}{l}\text { - Tempat menarik } \\
\text { h. Industri dan } \\
\text { Pergudangan }\end{array}$ & v & v \\
\hline & $\begin{array}{l}\text { - Industry kecil/rumah } \\
\text { tangga/UMKM }\end{array}$ & $v$ & $\checkmark$ \\
\hline & i. Bangunan & & \\
\hline & - Bangunan Gedung & $\checkmark$ & $\checkmark$ \\
\hline
\end{tabular}

Berdasarkan Tabel 9, perbandingan data antara hasil peta dengan PerKa BIG yaitu 23 dan 25. Sehingga presentase kesesuaian unsur kondisional sebesar $92,00 \%$ telah memenuhi syarat penyajian peta sarana prasarana kelurahan Panyuran. Sedangkan nilai 8,00\% yang tidak disajikan peda peta tersebut adalah penggambaran layer jalan pematang dan jembatan.

\section{KESIMPULAN}

Berdasarkan hasil penelitian tentang Analisa Kesesuaian Unsur Penyajian Peta Kelurahan Panyuran Berdasarkan PerKA BIG No.3 Tahun 2016, maka didapatkan kesimpulan akhir yaitu untuk mendapatkan tingkat kesesuaian sebesar 100\% dalam pembuatan peta kelurahan Panyuran yang mengacu pada Peraturan Kepala Badan Informasi Geospasial Nomor 3 Tahun 2016 maka semua unsur-unsur peta harus ditampilkan sebagai kewajiban/syarat penyajian peta desa. Peta citra harus memenuhi 7 layer wajib, 7 layer pilihan, dan 23 layer kondisional. Kemudian untuk peta tutupan lahan harus memenuhi 7 layer wajib, 4 layer pilihan, dan 27 layer kondisional. Sedangkan pada peta sarana dan prasaran harus terpenuhi 8 layer wajib, 5 layer pilihan, dan 25 layer kondisional.

\section{DAFTAR PUSTAKA}

Abidin, H. Z. 2017. Pemetaan Desa Untuk Percepatan Pembangunan Desa dan Kawasan Perdesaan. Jakarta: Badan Informasi Geospasial

Anonim. 2018. Website Desa. https://smartvillage.tuban kab.go.id/page/website-desa. Diakses pada 19 Juni 2019 jam 13.09 WIB

Peraturan Kepala Badan Informasi Geospasial Nomor 3 Tahun 2016 Tentang Spesifikasi Penyajian Peta Desa

Sukino, M. N. A. 2018. Analisis Pembuatan Peta Desa Skala 1:5000 Berdasarkan Peraturan Kepala BIG Nomor 3/2016. Surabaya: Departemen Teknik Geomatika Fakultas Teknik Sipil Lingkungan dan Kebumian Institut Teknologi Sepuluh Nopember

Undang-Undang Republik Indonesia Nomor 6 Tahun 2014 Pasal 1 Tentang Pengertian Desa

Undang-Undang Republik Indonesia Nomor 6 Tahun 2014 Pasal 78 Ayat 1 Tentang Pembangunan Desa 